\title{
Identification of Nepeta olgae Regel and phylogenetic status of some genera in subtribe Nepetinae (Lamiaceae) using DNA markers
}

\author{
Elena Nikitina , and Abdurashid Rakhmatov \\ Institute of Botany, Academy of Sciences of Uzbekistan, 100125 Tashkent, Uzbekistan
}

\begin{abstract}
The species level diversity is the reference unit for biodiversity accounting, should be systematized and include full information about the species. Reliable identification of any species is critical for a large-scale biodiversity monitoring and conservation. A DNA barcode is a DNA sequence that identifies a species by comparing the sequence of an unknown species with barcodes of a known species sequence database. Accurate identification of important plants is essential for their conservation, inventory. The species diversity assessing exampled on the subtribe Nepetinae (Lamiaceae) representatives, growing in Uzbekistan is given, using DNA barcoding method. The study was aimed to identify indigenous important plants with the nuclear (ITS) and plastid (matK, rbcL, trnL-F) genomes. This work demonstrates the phylogenetic relationships of some genera within the subtribe Nepetinae Coss. \& Germ. (Lamiaceae), based on ITS locus gene. All results indicate that the DNA barcoding tool can be successfully used to reliably identify important plants, to inventory the botanical resources of Uzbekistan and to create a reference library of DNA barcodes. So, the combination of three-four locus gene is a good candidate for this approach.
\end{abstract}

\section{Introduction}

According to modern estimates, there are about 308312 species of vascular plants on Earth [1]. More than 20,000 (40\%) species are endangered in nature: 4337 species are assigned the category Critically Endangered (CR, endangered), 7925 species - Endangered (EN, endangered) and 8098 species - Vulnerable (VU, vulnerable). The major threat factors include habitat transformation, overexploitation of natural resources, the spread of invasive alien species, environmental pollution and climate change [2]. Flora of Uzbekistan is rich in plant species diversity. It accounts over 4400 species of vascular plants, and includes a rare, relict species groups (10-12\% of the flora of Uzbekistan), 378 taxa are considered as a national endemics, the study of which makes possible to assess the processes of speciation

*Corresponding author: elenanikita2013@ rambler.ru 
in this region [3]. The disappearance of the vital components of biodiversity is one of the greatest threats for humanity.

Rare and endangered species require a special attention, regular monitoring of their natural populations and comprehensive study by classical taxonomy methods, as well as molecular genetic methods. Therefore, the rare important species of the subtribe Nepetinae Coss. \& Germ. (Lamiaceae) growing in Uzbekistan were chosen as objects of this study. Some genera that represent the subtribe Nepetinae in Uzbekistan are Nepeta L., Dracocephalum L., Drepanocaryum Pojark., Lophanthus Adans., Hyssopus L., Lallemantia Fisch. et C.A. Mey.

\section{Results and discussion}

The important and rare represents of the genera Nepeta, Dracocephalum, Lallemantia included in subtribe Nepetinae (Lamiaceae) growing in Uzbekistan were used as a research material. Lamiaceae are interesting due to a huge amount of biologically active compounds with a wide spectrum of action, medicinal and aromatic plants are using in traditional and modern medicine, pharmaceutics.

The genus Nepeta L. is one of the largest genus of subfamily Nepetoideae, tribe Mentheae (Lamiaceae) and accounts approximately 300 species, distributed in Eurasia [4]. It represents by 18 described species in Uzbekistan [5]. Nepeta olgae Regel is a member of this genus, endemic of Central Asia (Kyrgyzstan, Tajikistan, Uzbekistan). The collection of the genus in the National Herbarium of Uzbekistan (TASH) accounts 1333 specimens corresponding to 32 taxa collected around all regions of Central Asia.

The world flora accounts more than 70 species of the genus Dracocephalum L., Central Asia flora- 26 species, 16 species are expected to grow in Uzbekistan, including Dracocephalum adylovii I.I. Malzev [6]. The fund of the National Herbarium of Uzbekistan (TASH) contains more than 1738 herbarium specimens of Dracocephalum corresponding to 32 taxa collected in Central Asia.

The genus Lallemantia accounts five species native to central and southwestern Asia. In the flora of Uzbekistan the genus represents by the single species Lallemantia royleana.

The genus Salvia L. includes about 1000 species distributed throughout the world [7], 25 species are currently accepted for the flora of Uzbekistan. The National Herbarium of Uzbekistan (TASH) contains over 1800 herbarium specimens belong to 43 species of the genus Salvia.

Table 1. Species, studied in this paper

\begin{tabular}{|c|c|}
\hline Taxa & Distribution in Uzbekistan, coordinates, collectors, date of collection \\
\hline Nepeta olgae Regel & $\begin{array}{l}\text { Syrdarya river valley, Kyzylkum, Fergana Valley, Surkhan-Sherabad } \\
\text { Valley. Collected in Kugitang Ridge, Khatak village, Bagildar. Endemic of } \\
\text { Central Asia. } 37.960280 \mathrm{~N} 66.798898 \mathrm{E}, 1430 \mathrm{~m} \text {, } \\
\text { Rakhmatov, } 2020\end{array}$ \\
\hline $\begin{array}{l}\text { Dracocephalum } \\
\text { adylovii I.I. Malzev }\end{array}$ & $\begin{array}{l}\text { Western Tien Shan. Collected in Pskem ridge. between Tekesh and Ayutor } \\
\text { Rocks. Endemic of the Western Tian-Shan, Uzbekistan } \\
42.13066 \text { N } 70.8307 \text { E, } 2100 \mathrm{~m} \\
\text { Malzev, } 2018\end{array}$ \\
\hline $\begin{array}{l}\text { Lallemantia } \\
\text { royleana (Benth.) } \\
\text { Benth. }\end{array}$ & $\begin{array}{l}\text { Zaysan, Turgay, Alakol depression. Collected in Tarkapchigay, Kukzhar. } \\
38.28218 \mathrm{~N}, 66.22975 \mathrm{E}, 759 \mathrm{~m} \\
\text { Abduraimov, } 2019\end{array}$ \\
\hline Salvia korolkovii & Tien Shan: Karazhantau, Ugam, Pskem, Koksuy ridges, collected in Chatkal \\
\hline
\end{tabular}




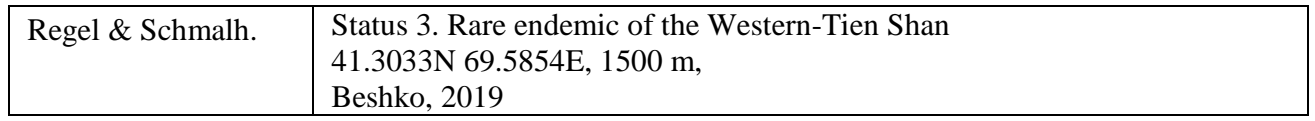

For effective species identification and high results reliability, the genotyping of threefour loci was performed for all studied species. Selected DNA regions (ITS1-ITS4, matK, $r b c L, t r n L-F)$ were amplified on a thermal cycler (BioRad) using the 2X PCR Taq Plus MasterMix with dye (Applied Biological Materials Inc., Canada). Amplification of the ITS region ( $~ 700$ bp DNA fragment) was carried out by using primers of the forward and reverse primer sets (ITS1, 5'-tccgtaggtgaacctgcgg-3'; ITS4, 5'-tcctccgcttattgatatgc-3') (TsingKe, China) as internal primers, matK region ( 850 bp DNA fragment size) (matK390F, 5'-cgatctattcattcaatatttc-3'; matK-1326R, 5'-tctagcacacgaaagtcgaagt-3'); rbcL region

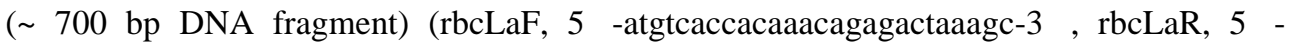
gtaaaatcaagtccaccrcg-3 $\square$ ); $t r n L-F$ intergenic spacer ( 900 bp DNA fragment) (trnL-F_F, 5' - cgaaatcggtagacgctacg -3'; trnL-F_R, 5' - atttgaactggtgacacgag- 3')

Table 2. Identification results of Nepeta olgae using 3-locus panel

\begin{tabular}{|c|c|c|c|}
\hline \multirow{2}{*}{$\begin{array}{l}\text { DNA- } \\
\text { barcode }\end{array}$} & \multicolumn{2}{|c|}{ Consensus nucleotide sequence } & \multirow{2}{*}{$\begin{array}{c}\text { Identification } \\
\text { number of } \\
\text { Database }\end{array}$} \\
\hline & (b.p) & $Q R$ code & \\
\hline matk & $\begin{array}{l}\text { TTTTAGAGGACAATTTTTCACATTT } \\
\text { AAATTTTGTGTTAGAGATACTAATA } \\
\text { CCTCGCTCTGTTCATGTGGAAATCT } \\
\text { TGATTCAAACTCTTCGCCATTGGGT } \\
\text { AAAAGATGTTTCTTCTTTATATTTA } \\
\text { TTAGGAGTATTTCTCAAGGAATATT } \\
\text { GGAATT...793 }\end{array}$ & 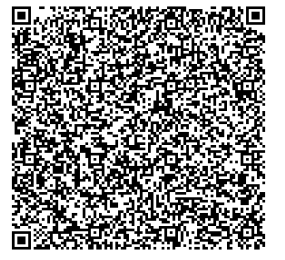 & $\begin{array}{l}\text { Nepeta cataria } \\
\text { maturase K (matK) } \\
\text { gene, partial cds; } \\
\text { chloroplast } \\
\text { GenBank: } \\
\text { MG947045.1 } \\
\text { Identities: } 98.68 \%\end{array}$ \\
\hline$r b c L$ & $\begin{array}{l}\text { TTATTATACTCCTGAATACGAAACC } \\
\text { AAAGATACTGATATCTTGGCAGCA } \\
\text { TTCCGAGTAACTCCTCAGCCTGGA } \\
\text { GTTCCGCCTGAAGAAGCAGGGGCC } \\
\text { GCGGTAGCTGCCGAATCTTCTACC } \\
\text { GGTACATGGACAACTGTGTGGACC } \\
\text { GATGGACTT..... } 681\end{array}$ & 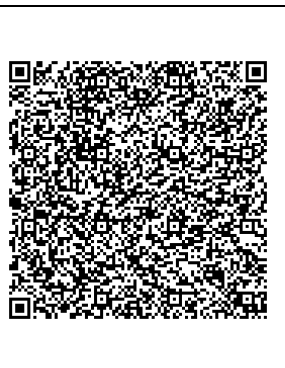 & $\begin{array}{l}\text { Nepeta coerulescens } \\
\text { ribulose-1,5- } \\
\text { bisphosphate } \\
\text { carboxylase/oxygen } \\
\text { ase large subunit } \\
\text { (rbcL) gene, partial } \\
\text { cds } \\
\text { GenBank: } \\
\text { MH293319.1 } \\
\text { Identities: } 99.39 \%\end{array}$ \\
\hline $\operatorname{trn} L-F$ & $\begin{array}{l}\text { AACTTACTAAGTGATAACTTTCAA } \\
\text { ATTCAGAGAAACCCTGGAATTAAT } \\
\text { AAAAATGGGCAATCCTGAGCCAAA } \\
\text { TCCTGTTTTCTCAAAGCAAAGGATA } \\
\text { GGTGCAGAGACTCAATG...... } 841\end{array}$ & 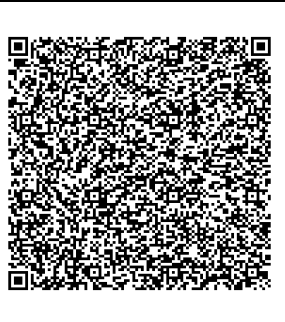 & $\begin{array}{l}\text { Nepeta glomerulosa } \\
\text { var. stapfiana } \\
\text { chloroplast gene for } \\
\text { tRNA-Leu (trnL), } \\
\text { IGS and tRNA-Phe } \\
\text { (trnF) } \\
\text { GenBank: } \\
\text { LC316167.1 } \\
\text { Identities: } 99.74 \%\end{array}$ \\
\hline
\end{tabular}

Based on the results of species genotyping, high level of amplification reproducibility results was demonstrated for all markers. The similarity with similar sequences in the BLAST database is $98 \%$ at least. Marker sequences for Nepeta olgae are presented to the database for the first time. Therefore, the result of comparing three sequences shown in the 
table, determined reliable similarity for each nucleotide sequence at the genus taxonomic level, Nepetae (Lamiaceae). Along with the standard format, the species marker sequences are presented as QR-codes (Quick Response Code).
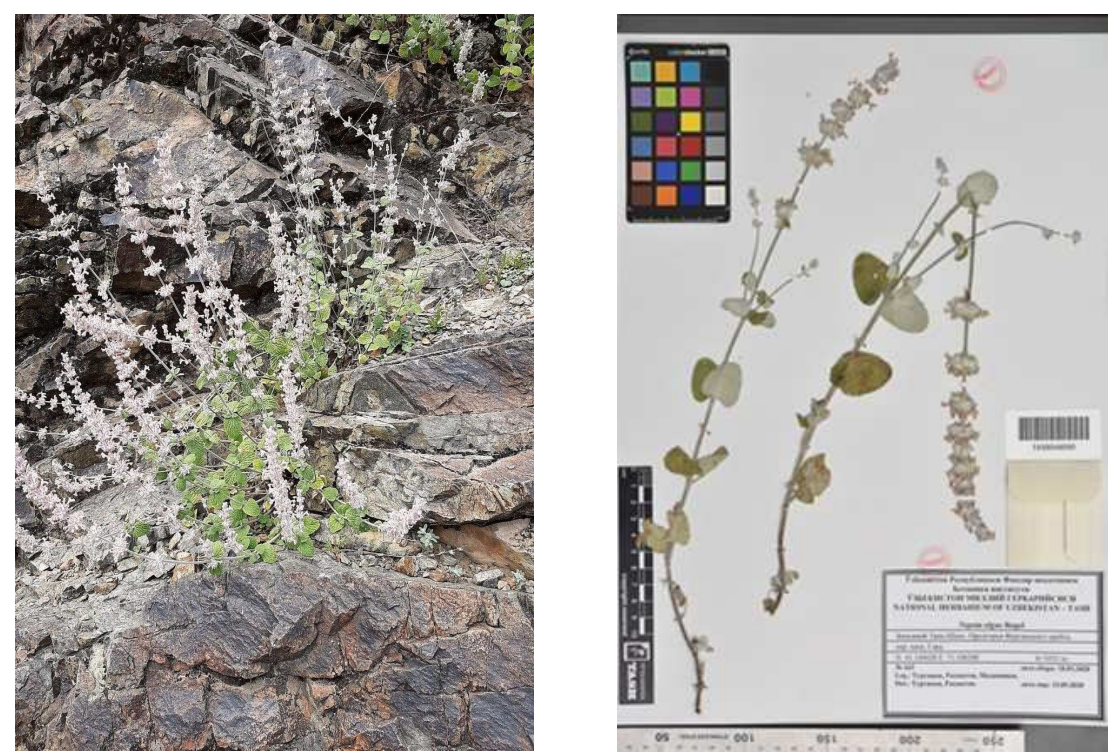

Fig. 1. Nepeta olgae Regel in nature and herbarium specimen in the National herbarium (TASH)

The dendrogram was constructed using nuclear region ITS data. It shows the phylogenetic relationships of some genera within the subtribe Nepetinae. The ITS region is commonly used to identify plants of different geographical origins for its high variability properties. The model choose was carried out using the jModelTest2.1.10 program [8]; reconstruction - with the maximum likelihood (ML) algorithm in MEGA5 program; the Bootstrap analysis (1000 replicas) were conducted to examine the topology reliability of the phylogenetic tree. The resulting graphic image was visualized in the FigTree v1.4.0. program (Fig.2).

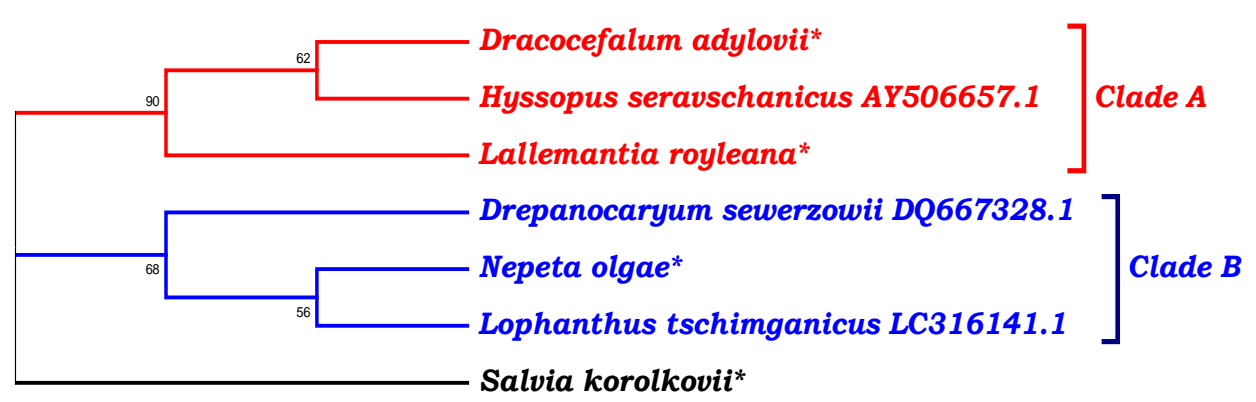

Fig.2. Hierarchical clustering of some genera within subtribe Nepetinae, constructed according to the sequence comparison of the ITS region 
According previous researches, the subtribe Nepetinae is monophyletic [9]. In our phylogenetic analysis results subtribe Nepetinae comprises two major evolutionary clades, and this fact confirms by other authors $[9,10]$. Thus, Clade A grouped representatives of three genera into a separate group: Dracocephalum, Hyssopus, Lallemantia. Clade has a wide distribution with at least three distinct lines towards North America.

The Clade B formed by the genera Drepanocaryum, Nepeta, Lophanthus. It is probably originated in the Mediterranean/Central Asia with spread to East Asia.

The formed cluster for Salvia korolkovii, used as an outgroup, establish the species independence and its belonging to tribe Mentheae.

Thus, this work demonstrates the effectiveness of using DNA barcoding as a tool for species diversity assessment of important plants in the flora of Uzbekistan.

\section{References}

1. M.vChristenhusz, J. Byng, 261 (3) (2016)

2. IUCN. The IUCN Red List of Threatened Species. Version 2020-3. https://www.iucnredlist.org. https://doi.org/10.15468/0qnb58

3. A. N. Sennikov, K. Sh. Tojibaev, F. O. Khassanov, N. Yu. Beshko, Phytotaxa 282 (2) (2016)

4. Z. Jamzad, M. W. Chase, M. Ingrouille, M. S. Simmonds, A. Jalili, Taxon 52(1) (2003)

5. A. I. Vvedensky, Flora of Uzbekistan (Tashkent, 1961)

6. N. S. Abdullaeva, O. K. Khojimatov, Journal of nature sciences 1 (2020)

7. M. Yousefiazarkhanian, A. Asghari, J. Ahmadi, B. Acghari, A. Ashraf Jafari, Notulae Botanicae Horti Agrobotanici Cluj-Napoca 44 (2) (2016)

8. D. Darriba, G. Taboada, R. Doallo, D. Posada, Nat. Methods 9 (2012)

9. B. T. Drew, K. J. Sytsma, American Journal of Botany 99 (5) (2012)

10. J. Li, J. Zhang, T. Deng, D.-G. Zhang, S. Volis, H. Sun, Z.-M. Li, J. Jpn. Bot. 92 (1) (2017) 